\title{
YOUNG GREAT HORNED OWL CALLS
}

\author{
WAYNE C. HARRIS, Box 414, Raymore, Saskatchewan. SOA 3J0
}

In the September 1982 Blue Jay the calls of young Great Horned Owls were the subject of an article entitled "The Great Gray Owls that weren't". "At the end of the article the authors asked whether others had heard calls which could be mistaken for those of young Great Gray Owis.

The "plaintive call" to which they referred is one with which I am quite familiar. I first heard the call as a teenager on a fall evening at our farm south of Raymore. I asked my father what they were and he replied that they were made by young Great Horned Owls.

These calls, which I refer to as "screeek" calls, have been heard regularly since then, both on our farm and at several localities around Saskatchewan; I had given them little thought until I read the aforementioned article, which prompted me to share my observations.

The earliest I have heard these calls is mid-July, the latest, late December. They are most frequently heard in August and September, tapering off in October and infrequently in November. Until December 1982 I can not remember hearing the calls past late November, however a bird which frequented our yard this year gave the calls on several occasions at dusk up to 15 December. Then near sunset on 30 December while bird-watching along the North Saskatchewan River north of Maidstone a Great Horned Owl was watched while giving this call.

I have always interpreted this as a hunger call of young Great Horned Owls begging food from adults who are trying to wean them from free hand-outs. This would seem to be verified from the an- tics of two young owls in our yard during 1981. The birds were raised in a nest about one-half mile from our house and began frequenting our yard in late July. They were seen nightly in early August often accompanied by an adult. The young birds never hooted but gave the "screeek" call; conversely the adults only hooted. The appearance of the adults diminished and possibly ceased around 10 August though the young remained. We began losing chickens on the 15th and on the night of 17 August I saw a young Great Horned Owl clutching a still struggling chicken in our chicken house. Using a flashlight I succeeded in catching the bird. The only entrance was a 10 -inch square hole at ground level, customarily left open as the chickens were in an enclosed pen. The previous night the young owl must have landed on the ground, walked into the house, captured a chicken and dragged it out through the same hole. Rather than kill the young owl, I transported it to the Last Mountain Lake Wildife Management Unit and released it, hoping it would not seek more domestic chickens and meet a somewhat less happy ending!

The chicken losses stopped for a couple of weeks as the poultry entrance was now closed at night. The other young owl remained a nightly visitor, and proved to be an intelligent individual. It entered the chicken house window by pushing aside the loose wire mesh, and escaped by the same route when the door was opened the next morning. The second night it pushed open the now nailed down mesh and killed two chickens, barely eating any of the flesh. This time it was captured in a five-gallon pail and transported for release in an area remote from inhabited farm yards near Big Quill Lake. 
This year (1982) all wire mesh windows were securely fastened and doors were closed at dusk; no chickens were lost to owls in spite of there being a young "screeeking" owl in our yard all fall.

Another experience with this call occurred in the Cypress Hills of southwestern Saskatchewan during the last weekend in September 1980. A "screeeking" owl was heard about onehalf mile from our campsite on Battle Creek. Imitations of adult Great Horned Owi calls brought the young bird to within 25 yards and it was clearly seen with the aid of a flashlight to be a Great Horned Owl.

Thus it would appear that both young Great Horned and Great Gray Owls give this food begging call. ${ }^{12}$ 3 I do not know whether young Barred Owls may also give this call. At dusk on 28 November
1981 between Squaw Rapids and Cumberland House, Saskatchewan a "screeeking" owl was heard but did not respond to Great Horned Owl imitations. The next night at about $1800 \mathrm{~h}$ less than 100 yards from where the "screeeking" was heard the previous night, a Barred Owl flushed from a road-killed Snowshoe Hare in the path of our headlight beams.

I would like to thank Stuart Houston for his helpfui comments on this article.

'HOUSTON, C. S., C. J. ESCOTT and R. C. GODWIN. 1982. The Great Gray OwIs that weren't. Blue Jay 409(3): 164-165.

${ }^{2}$ NERO, R. W. 1980. Great Gray Owl Phantom of the northern forest. Smithsonian Institute Press, Washington, D.C.

${ }^{3}$ PETERSON, R. T. 1962, Field guide to western bird songs. Houghton Mifflin Co., Boston.

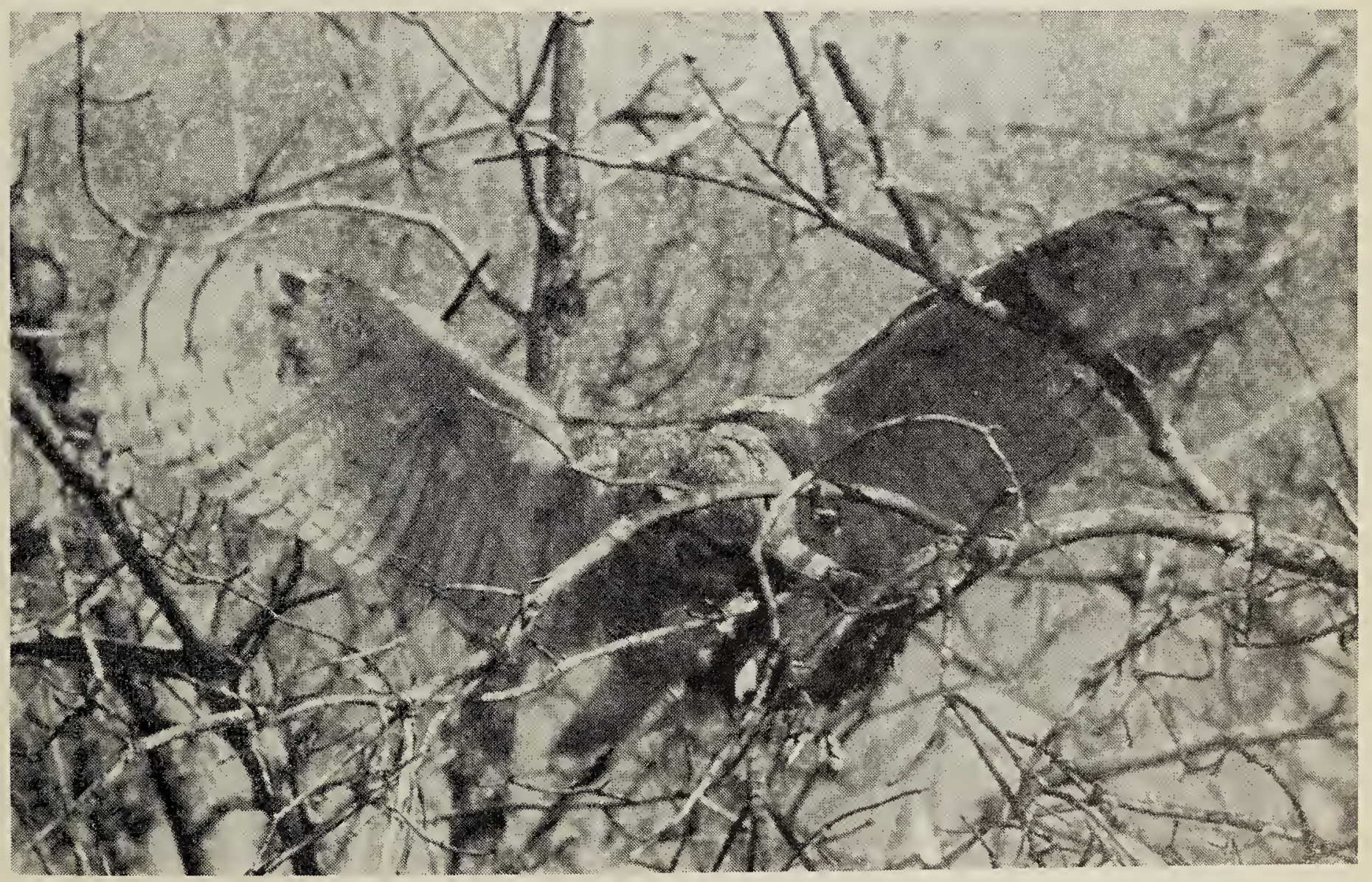

